This is the author's final, peer-reviewed manuscript as accepted for publication. The publisher-formatted version may be available through the publisher's web site or your institution's library.

\title{
Psychosocial factors predicting first-year college student success
}

Elizabeth J. Krumrei, Fred B. Newton, Eunhee Kim, \& Dan Wilcox

\section{How to cite this manuscript}

If you make reference to this version of the manuscript, use the following information:

Krumrei, E. J., Newton, F. B., Kim, E., \& Wilcox, D. (2013). Psychosocial factors predicting first-year college student success. Retrieved from http://krex.ksu.edu

\section{Published Version Information}

Citation: Krumrei-Mancuso, E. J., Newton, F. B., Kim, E., \& Wilcox, D. (2013). Psychosocial factors predicting first-year college student success. Journal of College Student Development, 54(3), 247-266.

Copyright: Published by The Johns Hopkins University Press

Digital Object Identifier (DOI): doi:10.1353/csd.2013.0034

Publisher's Link:

http://muse.jhu.edu/journals/csd/summary/v054/54.3.krumrei-mancuso.html

This item was retrieved from the K-State Research Exchange (K-REx), the institutional repository of Kansas State University. K-REx is available at http://krex.ksu.edu 


\section{Psychosocial Factors Predicting First-Year College Student Success}

Elizabeth J. Krumrei, Fred B. Newton, Eunhee Kim, \& Dan Wilcox

Elizabeth J. Krumrei is Assistant Professor of Psychology at Pepperdine University. Fred B. Newton is Professor Emeritus, Kansas State University. Eunhee Kim is Assistant Director of Institutional Research at Ohio Northern University. Dan Wilcox is Assistant Professor of Special Education, Counseling, and Student Affairs at Kansas State University. $<$ info $>$ Correspondence concerning this article should be sent to Elizabeth Krumrei, Social Science Division, Pepperdine University, 24255 Pacific Coast Highway, Malibu, CA 90263, elizabeth.krumrei@pepperdine.edu 


\section{Psychosocial Factors Predicting First-Year College Student Success}

Abstract: This study made use of a model of college success that involves students achieving academic goals and life satisfaction. Hierarchical regressions examined the role of six psychosocial factors for college success among 579 first-year college students. Academic selfefficacy and organization and attention to study were predictive of first semester grade point average (GPA) when controlling relevant demographic factors. Academic self-efficacy was even predictive of end-of-year GPA when controlling previous, first-semester GPA. Mediation analyses revealed that first-semester GPA was an important mediator between these two psychosocial variables and end-of-year GPA. Additional psychosocial variables were predictive of college students' life satisfaction: stress and time management, involvement with college activity, and emotional satisfaction with academics. We explore how formulating interventions on the basis of psychosocial factors offers an avenue for students to address specific attitudes, emotions, and behaviors that relate to college success.

Student success is at the heart of the educational enterprise. College success helps students to meet long-term personal and career goals and provides a range of monetary, psychosocial, and physical benefits (Baum \& Ma, 2007). For years, concern has been expressed about graduation rates (Swail, 2004). Only slightly more than half (57\%) of full-time students first going to a 4year institution seeking a bachelor's degree end up achieving that goal within 6 years (National Center for Education Statistics, 2010, Indicator 21). Furthermore, given the high rate of students who discontinue their education at their original institution, retention is a popular topic within higher learning. The Center for the Study of College Student Retention publishes a journal specific to the topic (Journal of College Student Retention: Research, Theory \& Practice) and 
provides a reference list of over 1,400 publications on student retention. In addition, the entrepreneurial market has developed numerous consulting organizations that aid universities in increasing retention.

Retaining students until graduation is often a direct fulfillment of the mission of institutions of higher learning. Colleges and universities are concerned with preparing students for productive roles in society. Students who terminate their education prior to graduation lose the time and finances that they have invested in the educational process without gaining the benefits of a degree. Admitting a student into the institution carries with it a certain level of commitment on the part of the institution to support the success of the student. Secondarily, retention is of concern to institutions for financial reasons. When students discontinue, a university is faced with the loss of campus resources that have been invested in the student as well as the loss of future revenue in the form of tuition.

Students discontinuing their education may reflect a failure on the part of the institution to support students' progress or respond to students' needs. Colleges and universities have invested a great amount of money in retention services (e.g., preparation courses, first-year seminars, academic success centers, advising interventions, tutorial programs, and counseling) in the hopes of retaining students through graduation. These represent substantial investments to improve student opportunities for success. Seidman (2005) indicated that promoting student success involves early identification of individual needs followed by a prescription for action. Psychosocial learning factors are useful points of intervention for professionals to actively promote student success (Krumrei \& Newton, 2009). Institutions of higher education are in need of assessments of psychosocial learning factors that can be used to customize interventions to students' characteristics (Peterson, Casillas, \& Robbins, 2006). Given institutional cost 
restraints, it would benefit colleges and universities to make use of tools in house rather than allocating substantial funding toward private consulting organizations promising retention results.

\section{Measuring College Student Success}

Tinto $(1987,2005)$ observed that efforts to promote student success are hampered when research focuses on student attrition rather than student persistence. Therefore, our goal in the current study was to identify factors that are critical to student success. Unfortunately, there is a lack of conceptual clarity within higher education research regarding definitions of college student success and the factors that lead to it (Robbins, Lauver et al., 2004). In selecting measures of student success, we made use of a simplified version of Pascarella and Terenzini’s (2005) foundational framework for synthesizing research on the ways that college impacts students. They divided types of outcomes among cognitive and affective criterions. For the current study, we selected one outcome that represents a cognitive measure (GPA) and one outcome that represents an affective measure (life satisfaction).

Grades traditionally have been viewed as the most important indicator of college performance and have been used as a criterion in psychological literature for almost a century (Lounsbury, Fisher, Levy, \& Welsh, 2009). In addition, some large-scale studies of student outcomes have made use of broader definitions of student success that include student satisfaction (e.g., Kuh, Cruce, Shoup, Kinzie, \& Gonyea, 2008). We followed the tradition of a number of studies in considering satisfaction an important outcome of higher education (e.g., Beltyukova, Stone, \& Fox, 2004; DeWitz, \& Walsh, 2002; Panori, Wong, Kennedy, \& King, 1995). Goodboy and Myers (2008) found that a variety of student factors are associated with student satisfaction as a learning outcome. Common measures of satisfaction among students 
assess positive emotions in the student's life as a whole, including personal satisfaction and satisfaction with university life (e.g., the College Descriptive Index, Reed, Lahey, \& Downey, 1984; the Quality of College Life, Sirgy, Grezeskowiak, \& Rahtz, 2007). The current study focused on students' satisfaction in a global sense, considering their levels of satisfaction with life as a whole during their time spent at college. From an institutional perspective, students making progress toward academic goals and experiencing satisfaction are both crucial to retaining college students (see Braxton, Brier, \& Steele, 2007, for a review). Failure to maintain a minimum GPA and a lack of life satisfaction during the college experience are each related to decreased retention rates (Wright, 2008; Yu \& Kim, 2008).

\section{Predicting College Student Success}

Researchers have long attempted to identify the factors that predict success among college students. For example, in 1958 Pierson identified that, among many different predictors of college success, the best predictor was previous (high school) grades. In addition, measures of aptitude such as the ACT and SAT commonly have been used to predict college success (Willingham, Lewis, Morgan, \& Ramist, 1990). Students' demographic factors, such as gender, ethnicity, financial status, and whether they are first-generation students, also have been shown to relate to college success (e.g., Pascarella, Pierson, Wolniak, \& Terenzini, 2004; Richardson \& Bender, 1987). After summarizing 39 studies predicting college GPA based on a range of factors including high school GPA, SAT scores, personality characteristics, and demographic factors, Mouw and Khanna (1993) concluded that overall our ability to predict college success on the basis of any of these factors is disappointingly low.

In 1992, Russell and Petrie offered a framework to provide counselors with a schema for conceptualizing and assessing student factors that could be used to counsel students on becoming 
more effective academically. They emphasized that student success relates to internal psychological traits (e.g., motivation, self-confidence, perceived support, and emotional impact) as well as external behaviors (e.g., study behaviors and campus involvement). The current study made use of this organizational framework for a comprehensive view of psychosocial factors that can be predictive of college success.

In a review of literature on college outcomes, Robbins et al. (2004) distinguished three types of predictors of college success: (a) traditional predictors such as standardized test scores,

high school rank, and GPA; (b) demographic predictors such as socioeconomic status, race, and gender; and (c) psychosocial predictors such as social involvement, motivation, selfmanagement, and study habits. Traditional predictors have been used most commonly in research, perhaps because they are useful for admissions decisions. Ironically, the practice of carefully selecting students for college admission on the basis of factors such as intelligence leads to decreased variance in these factors among students, making traditional predictors such as intelligence of lesser importance in accounting for differences in students' performance once they are in college. Furthermore, neither traditional predictors nor demographic predictors are useful as points of intervention for increasing success among students because they offer little room for change (Robbins et al., 2004). For these reasons, the current study focused on increasing knowledge of psychosocial factors and how they can be used to promote student success.

\section{Psychosocial Factors}

A number of studies have concluded that psychological factors are critical to success in the university setting (Chemers, $\mathrm{Hu}, \&$ Garcia, 2001). Furthermore, psychosocial factors have been shown to predict college retention and GPA even when controlling traditional predictors of 
college success. For example, Robbins et al.'s (2004) meta-analysis revealed that a number of psychosocial factors contributed incrementally to predicting college retention when controlling socioeconomic status, standardized achievement (ACT/SAT) scores, and high school GPA. In 2006, Robbins Allen, Casillas, Peterson, and Le published a study on the effects of psychosocial factors on 14,464 first-year college students at 48 institutions. While controlling institutional effects and traditional predictors, numerous psychosocial factors were incrementally predictive of academic performance (accounting for changes in GPA up to 0.28 points) and retention (with overall odds ratio of the logistic regression models ranging from 0.98 to 1.43 ). Thus, psychosocial factors seem to be powerful indicators of college success.

Consistent with the models of Russell and Petrie (1992) and Kim, Newton, Downey, and Benton (2010), the current study focused on six psychosocial factors that (a) have been related to indices of college success in the research literature and (b) are within the power of the individual to influence, direct, or enhance in some way. They are: academic self-efficacy, organization and attention to study, stress and time management, involvement with college activity, emotional satisfaction with academics, and class communication.

Academic self-efficacy. Bandura's (1977) foundational theory of self-efficacy describes that a person's beliefs about his or her ability to successfully perform a given task will determine the level and length of effort expended. Research has shown that students' self-efficacy is predictive of academic adjustment (Friedlander, Reid, Shupak, \& Cribbie, 2007), higher grades and longer persistence in technical/scientific majors (Lent, Brown, \& Larkin, 1984), college satisfaction (DeWitz \& Walsh, 2002), and re-enrollment decisions among first-year college students (Davidson \& Beck, 2006). In Robbins et al.’s (2004) meta-analysis, academic selfefficacy was highly related to increased college retention and academic self-confidence and 
achievement motivation were the best predictors of cumulative college GPA.

A longitudinal study of first-year university students revealed that academic self-efficacy was strongly related to better academic performance, both directly as well as indirectly through academic expectations (Chemers et al., 2001). These findings remained after accounting for the effects of high school GPA. Because high school GPA might also be related to academic selfefficacy, this was a conservative indication that self-efficacy is not merely a byproduct of academic ability. Chemers et al. (2001) also reported significant mediated effects of academic self-efficacy on satisfaction and commitment to remain in school. Highly efficacious students tended to believe that they possessed coping abilities adequate to their academic pressures, which was related to less stress, better health, and better adjustment.

We expand previous research on this topic by examining students' confidence in academic ability and expectations of attaining success in college. Chemers et al. (2001) did not measure the specific attitudes and behaviors that might mediate the relationship they observed between self-efficacy and academic performance. The current study assessed whether habits and behaviors, such as organization and attention to study, involvement with college activity, and class communication, are relevant to academic success in addition to self-efficacy.

Organization and attention to study. Macan, Shanhani, Dipboye, and Phillips (1990) found that time-management behavior was associated with better academic performance and greater life satisfaction. Specifically, academic performance was positively related to (a) setting goals and priorities, (b) planning and scheduling, (c) perceived control of time, and (d) preference for organization. Life satisfaction was positively correlated with (a) planning and scheduling and (b) perceived control of time. Along similar lines, Arthur, Shepherd, and Sumo (2006) found that level of student diligence was predictive of higher GPA. Gortner, Lahmers 
and Zulauf (2000) and Nonis, Philhours, and Hudson (2006) used time diaries as direct measures of time management among students. Each study observed that amount of time spent studying was positively related to students' GPAs.

In Robbins et al.'s (2004) meta-analysis, academic-related skills, achievement motivation, and academic goals strongly predicted higher college GPA and were related to college retention. Specifically, academic discipline, which included both the amount of effort students invested in schoolwork and the extent to which they identified as conscientious and hardworking, was incrementally predictive of GPA and retention after controlling institutional effects and traditional predictors of college success. The current study built on previous research by assessing organization and attention to study, defined according to a student's use of skills to organize tasks, structure time, set goals, and plan and carry out necessary academic activities.

Stress and time management. The American College Health Association has found that stress is the most commonly reported health impediment to students' academic performance (e.g., American College Health Association, 2009). Several longitudinal studies among firstyear college students have confirmed that stress is associated with less positive adjustment to college over time. For example, Chemers et al. (2001) observed that students who experienced more stress tended to be less well-adjusted in that they experienced less satisfaction with academic progress and lower commitment to remain in school. Wintre and Yaffe (2000) found that stress was predictive of decreased adaptation to university among males and females as well as decreased GPAs among females. Pritchard and Wilson (2003) observed that stress was a negative predictor of GPA, even after controlling for demographic variables. Similarly, Friedlander et al. (2007) found that decreases in stress were associated with improved academic adjustment and a host of other forms of adjustment. 
Although past research has often focused on the nature and amount of stress experienced by students, we extend this research by focusing on the counterpart: students' ability to respond to time pressure, concerns in the immediate environment, and academic demands without becoming overwhelmed and without relying on procrastination or avoidance techniques. Previous research has emphasized that the time students devote to educational activities is the best predictor of their learning and personal development (see Pascarella \& Terenzini, 2005, for a review). We extended the research on the number of hours devoted to educational activities by assessing students' skills and abilities related to managing time effectively and coping with stressors rather than becoming debilitated by them.

Involvement with college activity. Another psychosocial predictor of college success is involvement with college activity. Astin (1984/1999) defined student involvement as the amount of physical and psychological energy that a student devotes to the academic experience. This includes devoting energy to studying, spending time on campus, participating actively in student organizations, and interacting with faculty members and other students. Student involvement theory holds that student learning is increased when there is more involvement in both academic and social aspects of the collegiate experience. More specifically, Astin stated that student learning and personal development associated with any educational program is directly proportional to the quality and quantity of student involvement in that program. Rather than viewing a student as passively being developed by outside forces such as university programming, this theory places the student at the center of decision making about involvement in college classes and extracurricular activities.

In Robbins et al.'s (2004) meta-analysis, social involvement was moderately related to higher college retention and GPA. In addition, the related variables of social support and 
institutional commitment were moderately related to greater college retention. In Robbins et al.'s (2006) large-scale study, students' feelings of connection and involvement with the college community was incrementally predictive of retention when controlling for institutional effects and traditional predictors of college success. In addition, social activity, which they defined as students' comfort levels in meeting and interacting with others, was predictive of higher retention and GPA. Kuh et al. (2008) examined the importance of the time and energy students invest in educationally purposeful activities with data from 18 institutions. They found that student engagement positively affected grades in the first and last year of college and affected persistence from the first to the second year of college at the same institution, even after controlling a host of pre-college characteristics and other variables linked with these outcomes (e.g., merit aid and parental education). Furthermore, although research has shown that demographic characteristics are differentially related to indices of college success, Kuh et al. found that the effects of student engagement were generally in the same positive direction for students from different races and ethnicities. Thus, student involvement can be considered an equalizing force in higher education.

In the current study, we took a behavioral approach in defining involvement with college activity as students' participation in university activities and membership in organizations. On the basis of student involvement theory (Astin, 1984/1999), we were inclusive of many forms of involvement in the academic community, such as formal and informal campus activities and involvement with academic and nonacademic college organizations.

Emotional satisfaction with academics. Emotional concerns, such as depression and anxiety, frequently have been ranked fifth and sixth among common health impediments to students' academic performance (e.g., American College Health Association, 2009). Studies 
have indicated that emotional health is predictive of students' GPA and intent to drop out of college (Pritchard \& Wilson, 2003). In the current study, we extended previous research by examining emotional satisfaction specific to academic life. This includes a range of affective responses to academics, such as students' degree of interest in and positive anticipation about instructors, classes, and other aspects of their educational environment.

Class communication. Class communication frequently has been associated with an increase in grades (see Goodboy \& Myers, 2008, for a review), however, the majority of research on the topic has been conducted among kindergarten through $12^{\text {th }}$ grade students rather than with college students. Rocca (2010) reviewed research from the past 50 years on student participation in the college classroom, indicating that instructors, students, and researchers alike report that class participation is important to academic success. Smith (1977) found that the degree of student participation in class - consisting of communicating responses from memory, communicating convergent or divergent responses to others, communicating evaluative responses, and peer-to-peer interaction — was consistently positively related to critical thinking (e.g., interpretation, analysis, and synthesis) among students in 12 college classes spanning a range of disciplines. More recently, Arthur et al. (2006) found that students' level of class participation was indirectly related to higher GPA through the construct of diligence. Handelsman, Briggs, Sullivan, and Towler (2005) found that greater participation and engagement in class interaction directly predicted higher midterm and final exam grades among first-year college students.

Perhaps the relationship between student communication and positive academic outcomes results from the well-documented link between active involvement and learning (see Weaver \& Qi, 2005, for a review). This fits within Tinto's (1987) conceptual framework, which 
emphasizes that active student involvement in the learning process is critical. It is also consistent with Astin's (1984/1999) theory that instructors can achieve maximum student learning by increasing active communication. According to Astin, frequent interaction with faculty is more strongly related to satisfaction than is any other student or institutional characteristic. In the current study, we extended the research available on class communication in college students by considering both verbal and nonverbal efforts of students to engage in class activity. We assessed students expressing their ideas in written and oral communication within class and outside of class with instructors.

\section{The Current Study}

Psychometrically sound and theory-based measures of psychosocial factors are needed to advance our understanding of the role of psychosocial factors in college student success (Robbins et al., 2004). We used an extensive measure to examine the power of a host of psychosocial factors to predict college success at a public university in the Midwestern United States. We expected that academic self-efficacy, organization and attention to study, stress and time management, involvement with college activity, emotional satisfaction with academics, and class communication would statistically account for variance in GPA and life satisfaction among a sample of first-year college students. Furthermore, we expected that these psychosocial factors would predict outcomes net of the variance attributable to demographic factors and previous GPAs.

\section{METHOD}

\section{Participants}

Data were collected at a major public research university located in the Midwest in the United States. Enrollment totaled 23,500 students. As a land grant institution, the university is 
committed to serving the interest of the general population of the state, including agriculture, education, and applied sciences. A sample of 579 first-year college students participated during the 2008-2009 academic year. Their ages ranged from 18 to 23 years, with an average of 18.24 years at the initial assessment. A majority of participants were women (64.6\%). The vast majority of participants (90.5\%) identified as Caucasian; additionally, 2.8\% identified as African American, $2.8 \%$ as Latino, $2.4 \%$ as multiracial, $1.2 \%$ as Asian American, and $0.3 \%$ as Native American. Most participants lived in residence halls on campus (81\%), with an additional 11.2\% living in fraternity/sorority houses. Participant retention for the repeated measures was $96 \%$; therefore analyses involving end-of-year GPA were conducted among 557 participants.

\section{Procedure}

Participants were recruited from introductory academic courses. They received bonus credit in their courses as an incentive for participation. Participants completed self-report measures via the Internet during their first semester at the university. First-semester and second-semester GPAs were obtained as objective measures from the university's student record system.

\section{Measures}

Psychosocial factors. We made use of the College Learning Effectiveness Inventory (CLEI; Newton, Kim, Wilcox, \& Beemer, 2008), which assesses personal attitudes, behaviors, and dispositions relevant to academic success. Descriptions of the six scales of the CLEI (Academic Self-Efficacy, Organization and Attention to Study, Stress and Time Management, Involvement with College Activity, Emotional Satisfaction with Academics, and Class Communication) along with sample items are provided in Table 1. The CLEI was administered in an on-line format. Items were rated on a 5-point Likert-type scale ranging from 1 (always) to 5 (never). Upon completion, the CLEI generated feedback of the results to participants in the form of a profile 
and interpretation guide.

\section{$<$ Insert Table 1 here $>$}

The CLEI was developed by two panels of professionals with expertise in student learning, educational psychology, and psychometrics. A large number of items were generated on the basis of Russell and Petrie's (1992) theoretical model of student success that emphasizes the importance of internal psychological traits (e.g., motivation, self-confidence, perceived support, and emotional impact) and external behaviors (e.g., campus involvement and approach to study). Based on two rounds of pilot testing $(N=500), 62$ items were selected for an exploratory factor analysis $(N=597)$. This resulted in six factors, with 44 items meeting criteria for inclusion. Subsequently, a confirmatory factor analysis was conducted to examine whether the factor structure adequately applied to a replication sample $(N=292)$. The fit indices of the six-factor model displayed acceptable values (i.e., ratio of $\chi^{2}$ goodness-of-fit statistic to $d f=1.70$, $S R M R=.084, R M S E A=.050, C F I=.96)$. Additional information on scale development is available (Kim et al., 2010).

The CLEI has met acceptable standards as a reliable and valid instrument. Four of the six factors displayed adequate reliabilities (ranging from .79 to .87), and two factors with relatively smaller numbers of items displayed marginal reliabilities: Emotional Satisfaction with Academics (.68) and Class Communication (.64). The trends for internal consistency in the current study were similar to those in the scale development study (ranging from .67 to .84; see Table 2). Construct validity of the CLEI has been tested on a validation sample of 160 students (Yeager, 2009). The CLEI scales have been validated against external measures including measures of learning and study strategies, self-esteem, college adjustment, and class participation. 


\section{<Insert Table 2 here>}

Life satisfaction. Items from the Satisfaction with Life Scale (Pavot \& Diener, 1993; five items, $\alpha=.87$ ) were used to assess students' levels of life satisfaction. The current study made use of the following three items: "I am satisfied with my life," "The conditions of my life are excellent," and "In most ways my life is close to my ideal." Items were rated on a 5-point Likert-type scale ranging from 1 (strongly disagree) to 5 (strongly agree). The internal consistency for the current sample was .84 .

Grade point average. College GPAs were used as an objective measure of academic performance. GPA data were gathered through the university's records system at the end of participants' first and second semesters in college.

Demographic variables. Gender and ethnicity were assessed. Given that over $90 \%$ of the students identified as Caucasian, ethnicity was grouped into "majority" (Caucasian) and "minority" (other than Caucasian). The values of demographical variables were coded either 1 or 0 (i.e., male $=1$ and female $=0$; majority $=1$ and minority $=0$ ) for data entry. The study was limited to first-year college students providing homogeneity for year in school and age.

\section{RESULTS}

\section{Descriptive Information and Zero-Order Correlations}

Descriptive statistics ( $M, S D$, range, internal consistency) and Pearson's zero-order correlations of the study's variables are presented in Table 2. Results from the correlation analyses indicated significant links between the CLEI scales and college outcomes. The CLEI scales administered during the first semester of college were positively correlated with first-semester GPA ( $r=.16$ $\sim .36)$, end-of-year GPA ( $r=.09-\sim .34)$, and life satisfaction $(r=.27-\sim .38)$.

Each of the CLEI scales was significantly correlated with GPA, with the strongest links 
for Academic Self-Efficacy ( $r=.36$ for first-semester GPA and $r=.34$ for end-of-year GPA) and Organization and Attention to Study ( $r=.31$ for first-semester GPA and $r=.24$ for end-of-year GPA). Similarly, each of the CLEI scales was significantly correlated with Life Satisfaction scores, with the strongest links for Stress and Time Management $(r=.38)$, Emotional Satisfaction with Academics $(r=.37)$, and Involvement with College Activity $(r=.36)$.

\section{Psychosocial Factors Predicting College Outcome}

Hierarchical linear regression analyses were conducted to examine the incremental effects of the CLEI scales for predicting college outcomes. Three separate analyses were conducted to estimate the effects of the CLEI on each of three criterion variables: first-semester GPA, end-ofyear GPA, and life satisfaction. We controlled relevant demographic factors (i.e., gender and majority/minority status) by entering them in step one of the regression. First-semester GPA was entered as an additional control in the model predicting end-of-year GPA. The six CLEI scales were entered in the final step of each analysis.

CLEI predicting first-semester GPA. Results from the hierarchical regression analyses indicated students' scores on the CLEI contributed incrementally to variance in first-semester GPA (Table 3, Panel A). The final model explained 17.7\% of the total variance in first-semester GPA $\left(R^{2}=.177\right)$, with the CLEI scales accounting for $16.3 \%$ of the variance in first-semester GPA after taking into account relevant demographic factors. Academic Self-efficacy had the largest positive influence on first-semester GPA $(\beta=.30)$ followed by Organization and Attention to Study $(\beta=.22)$. The other CLEI scales (Stress and Time Management, Involvement with College Activity, Emotional Satisfaction with Academics, and Class Communication) did not account for statistically significant proportions of variance.

$<$ Insert Table 3 here $>$ 
CLEI predicting end-of-year GPA, controlling first-semester GPA. Results from the hierarchical regression examining whether the CLEI was predictive of end-of-year GPA net of the effects of first-semester GPA are provided in Table 3, Panel B. The final model explained $47.8 \%$ of the total variance in end-of-year GPA $\left(R^{2}=.478\right)$. Although the CLEI scales accounted for only a modest proportion of the variance $\left(R^{2}=.023\right)$ in the model, it is noteworthy that an effect on end-of-year GPA remained net of the effects of first-semester GPA and demographic factors. Academic Self-efficacy was the only significant predictor among the CLEI scales $(\beta=.17)$.

Indirect effects of CLEI on end-of-year GPA through first-semester GPA. A multiple independent variables mediation analysis was conducted to assess whether the six psychosocial factors were related to end-of-year GPA through first-semester GPA (see Table 4). We made use of 1,000 bootstrap samples (Preacher \& Hayes, 2004) to test mediation with $95 \%$ confidence intervals that correct for biases in the sampling distribution. In each analysis, we statistically controlled for gender and ethnicity of the participants. First-semester GPA acted as a positive, partial mediator between academic self-efficacy and end-of-year GPA (50\% of the effect was mediated). Furthermore, first-semester GPA acted as a positive, full mediator between organization and attention to study and end-of-year GPA (100\% of the effect was mediated).

\section{$<$ Insert Table 4 here $>$}

CLEI predicting life satisfaction. Results from the hierarchical regression analyses indicated that students' scores on the CLEI contributed incrementally to the variance in their overall life satisfaction (Table 5). The final model explained $25.0 \%$ of the total variance in overall life satisfaction in the first year $\left(R^{2}=.25\right)$, with the CLEI scales accounting for $24.5 \%$ of the variance in life satisfaction, controlling for relevant demographic factors. Stress and Time 
Management $(\beta=.27)$ and Involvement with College Activity $(\beta=.26)$ were the strongest predictors followed by Emotional Satisfaction with Academics $(\beta=.10)$. The other CLEI scales (Academic Self-Efficacy, Organization and Attention to Study, and Class Communication) did not account for statistically significant proportions of variance in life satisfaction.

\section{$<$ Insert Table 5 here $>$}

\section{DISCUSSION}

This study represents an initial step to demonstrate the usefulness of psychosocial assessment in targeting college success. The results indicated that participants' psychosocial variables were relevant to outcome measures of success. Academic self-efficacy and organization and attention to study were predictive of first-semester GPA when controlling relevant demographic factors. Academic self-efficacy was even predictive of end-of-year GPA when controlling previous, firstsemester GPA. Mediation analyses revealed that first-semester GPA was an important mediator between these two psychosocial variables and end-of-year GPA. Other psychosocial variables that were predictive of college students' life satisfaction included: stress and time management, involvement with college activity, and emotional satisfaction with academics. Class communication was the only assessed psychosocial factor that was not directly associated with GPA or life satisfaction.

Interestingly, different psychosocial variables related to GPA and life satisfaction in the current sample. Our position is that holistic student success involves both academic performance and life satisfaction. Furthermore, research has linked both of these outcome measures to student retention (e.g., Wright, 2008; Yu \& Kim, 2008). Therefore, we will discuss each psychosocial factor that was associated with either GPA or life satisfaction with the goal of exploring how each psychosocial domain can be assessed and used to promote success among students. 
Even though the assessed psychosocial factors accounted for a limited portion of the total variance in students' academic success, we believe they are noteworthy because institutional interventions can target change in these areas (Zhao \& Kuh, 2004), unlike other variables related to student success (such as level of intelligence or general aptitude). With guidance and support, students are able to make adjustments toward more successful attitudes, behaviors, and dispositions, which our data suggests could be related to better academic performance and higher life satisfaction among students.

Academic institutions often ask faculty and staff to be responsive to the psychosocial needs of students. Reaching this goal requires specificity in approach. The psychosocial factors addressed in this study offer a framework for thinking about and addressing the individual needs of students. Astin (1984/1999) stated that the effectiveness of any educational policy or practice is directly related to the capacity of the policy or practice to increase student involvement. Focusing on students' individualized psychosocial factors is one method for increasing the likelihood that students will be personally invested and actively involved in an academic success plan.

Psychosocial factors related to GPA. One of the findings of this study was that the psychosocial factors that predict end-of-year GPA (academic self-efficacy and organization and attention to study) act for a large part through first-semester GPA. This has clear implications for the appropriate timing of interventions. These findings suggest that addressing academic self-efficacy and organization and attention to study early in students' academic careers is the most advantageous means of influencing longer-term GPA. This may be counter-intuitive to student support staff who wait for direct measures of achievement, such as grades, to identify when intervention is needed. The current data suggest that identifying psychosocial variables 
earlier in higher education may provide opportunities for effective intervention during the critical window of students' first academic semester, before course grades are available.

Academic self-efficacy involves a student's beliefs about his or her ability to reach desired goals and successfully complete tasks. The current results extend previous findings that academic self-efficacy is predictive of better academic performance (Chemers et al., 2001). Consistent with Bandura's (1977) theory, it is likely that feeling efficacious in academic tasks results in more effort and longer persistence through difficulties, which might account for higher achievement.

Thus, it is relevant to consider factors related to poor academic self-efficacy and how they can be overcome. One possibility is that students with low self-efficacy lack academic skills and therefore have accurate perceptions of low efficacy. However, this does not account for all cases of low self-efficacy among the current sample, as this variable was only moderately related to a measure of academic skills (organization and attention to study, $r=.46, p<.01$ ). In instances where self-efficacy views are not based on ability to perform academic tasks, students may experience poor academic performance as the result of low self-efficacy becoming a selffulfilling prophecy. Students who have low efficacy expectations may be less persistent, extend less effort, and avoid academic tasks. This in turn can decrease performance on tests and assignments, reinforcing the negative efficacy perceptions.

Gathering information about academic skills, such as organization and attention to study, can help identify situations in which a lack of skill is at the root of low self-efficacy and/or directly related to poorer academic performance. In such instances, problems can be addressed directly by promoting skills such as the ability to structure time and tasks, set goals, plan, and carry out academic responsibilities. Students who lack abilities in the arena of organization and 
attention to study may benefit from educational or career counseling.

Psychosocial factors related to life satisfaction. Previous research has highlighted that students' self-perceived stress levels are predictive of academic adjustment (Friedlander et al., 2007). Rather than conceptualizing stress as an external force beyond the students' control, the current study enriches previous research by using a model of stress that is based on students' perceived skills for responding to time and task demands. This variable was directly related to students' levels of life satisfaction. Students who lack skills for responding to stress and time pressures may rely on procrastination or avoidance and would therefore likely benefit from interventions that focus on coping with stress and increasing confidence for managing academic demands. Most college campuses provide resources for students to learn techniques such as stress management and relaxation training (e.g., counseling centers). Previous research has shown that stress levels fluctuate with the academic calendar (Friedlander et al., 2007). Therefore, outreach and intervention can be timed at appropriate junctures during the year. In this study, engagement with college activity and emotional satisfaction with academics were each also related to life satisfaction. However, findings related to students' emotional satisfaction with academics in this study must be interpreted with caution due to the marginal reliability of the Emotional Satisfaction with Academics scale $(\alpha=.67)$. Previous research has highlighted that social interaction and connection is important to student retention in college (e.g., Braxton et al., 2007). Academic and student affairs professionals may wish to identify students who are isolated in order to facilitate opportunities for them to become engaged in campus activities. In working with students expressing discouragement or negative reactions to academic life, professionals should keep in mind that emotional satisfaction with academics may not be the result of characteristics of the institution or the student, but may reflect a lack of 
goodness of fit between the two (Tinto, 1987). Thus, students with low emotional satisfaction with academics may benefit from finding a better niche within their university community (e.g., a major that matches better with their interest and skills). Increasing compatibility between the student and the college setting may increase emotional satisfaction with academics and thereby promote overall life satisfaction.

Class communication. Class communication was the only variable that was not significantly linked to either GPA or life satisfaction among the current sample. Nevertheless, class communication can be linked conceptually to the other assessed factors (e.g., organization and study activities can prepare students to provide class input and successful class communication can promote academic self-efficacy). Rocca's (2010) review of research on classroom participation revealed that, even though instructors, students, and researchers find class participation important, most students either are not active in class communication or participate at very low levels. Weaver and Qi (2005) offered a path analysis showing that the factors most influential for participation were faculty-student interaction outside of class, students' perception of professor as the authority of knowledge, students' fear of peer disapproval, engagement in paraparticipation, students' ages, and students' levels of confidence. For follow up on this topic, Rocca (2010) and Weaver and Qi (2005) offered suggestions about how instructors can organize courses to promote class discussion and engagement.

\section{Implications for Practice}

Recent research has strongly challenged the American higher education system, revealing that many students are making little to no gains in general analytical competencies such as critical thinking, complex reasoning, and written communication during their first two years of college (Arum \& Roksa, 2011). A specific way in which institutions can take greater responsibility for 
student learning is to increase awareness about students' psychosocial variables through assessment. Assessing strengths and weakness among psychosocial factors may be useful for students who are on probation, underperforming, readmitted to the institution, considered at risk, or individually wanting to improve their academic performance. Assessment should be followed by interventions targeting specific student needs. Assessment and intervention can take place on a group or individual basis.

Group strategies. Group programming can be used to educate students and prevent academic problems. Assessment can be used to identify the needs of particular subgroups within the university community, such as first-time college students. For example, assessment of psychosocial learning factors can take place in first-year experience/orientation classes as a method of introducing students to topics that are essential for managing college level work. Skill-building sessions can be built into these classes aimed at improving student capabilities in relevant areas such as study, time management, personal goal setting, etc. Peer mentoring programs also can be implemented with the same goals.

In addition to preventative work, there is also the need for intervention with students who require remediation following academic probation or re-entry from academic suspension. For these groups, a stage-level intervention can be employed in which psychosocial variables are assessed in the process of identifying and exploring problem areas, followed by developing a plan of strategies for improvement and a program to implement change.

Individual strategies. Often when students fail to achieve acceptable GPAs or choose to discontinue their education due to a lack of satisfaction in their educational setting questions arise about the factors that contributed to the situation. Frequently, psychosocial factors are recognized when it is too late for correction. Therefore, there is a need for early detection of 
concerns among individual students to facilitate open communication with appropriate support staff. One method would be to provide an assessment of psychosocial factors as a self-help tool at a student resource website. With this modality, students can receive a results profile about their psychosocial variables along with information about their personal strengths and weaknesses. Follow-up information, including written resources and campus referral services, can be provided.

Advising and learning assistance centers working individually with students who need or desire to evaluate their learning process can begin by assessing psychosocial variables. It is helpful to have discussions that delve into the personal and social influences related to student learning. Reviewing the results of a psychosocial measure can increase students' awareness of their personal characteristics as learners. This guides the conversation past a simplistic discussion about the need to work harder to a deeper discussion of specific factors that are impeding the student's learning. This information can be used to prepare an academic success plan that is based on action interventions. It is important for students to take responsibility for setting and completing goals. This can be encouraged through a program-of-change contract, which outlines the specific steps a student agrees to take in order to improve his or her learning behavior. Regular meetings can be held to monitor and support the student's progress. This likely would be most effective when professionals trained to assist students with academic problems (advisors, counselors, learning center staff) guide students.

Self-efficacy interventions. We conclude with a more detailed consideration of intervention related to the psychosocial variable that exhibited the most robust findings in this study: academic self-efficacy. We propose four ways to intervene with students with low selfefficacy corresponding to Bandura's (1997) four sources of self-efficacy: (1) creating 
opportunities for successful performance, (2) finding role models, (3) experiencing encouragement and support, and (4) managing anxiety when performing in areas of low selfefficacy.

An initial strategy is to help students increase opportunities for successful performance. Professionals can aid students in selecting courses in which success is probable. For example, courses that are designed so that students learn in smaller units and master portions of material before moving to the next unit increase the likelihood of success. In addition, students can learn to set proximal goals in order to insure more frequent success experiences (Luzzo, Hasper, Albert, Bibby, \& Martinelli, 1999). Providing ways for students to document their progress is also recommended as a method for helping students to recognize their successes.

Second, finding role models in in the domain where the student lacks efficacy is a helpful strategy for increasing self-efficacy. Students can be encouraged to observe peers who are performing successfully. Where relationships with individuals in the academic community are not available, students can learn vicariously from characters in books or films.

Third, expressing confidence in a student's abilities and providing encouragement builds self-efficacy. Positive feedback is especially helpful related to new experience in a feared area. Coaching students to be their own source of positive feedback and to amplify small successes is another way to increase efficacy beliefs. For example, students can reflect on their positive progress in a daily journal. Students struggling with low efficacy can be guided to self-regulate by selectively attending to positive feedback and encouraging words from others and by learning to minimize the impact of harsh criticism or judgments from peers or teachers.

Finally, it is recommended that students learn anxiety and stress management techniques to cope with the negative emotions and physiological arousal that often accompany performance 
in areas where students lack confidence. Such strategies include physical relaxation techniques and cognitive methods related to disputing negative, pessimistic thinking and self-doubt. For example, students can practice changing their negative self-attributions and self-talk (e.g., 'I'm a failure" or "I'm never going to get this").

These methods for increasing academic self-efficacy are most powerful when used in combination with one another rather than in isolation. Further, intervention can be strengthened when professionals in the many different domains of higher education work together to promote student success. For example, faculty members can contribute by using classroom strategies that enhance self-efficacy and decreasing strategies that exacerbate anxiety or further entrench negative self-efficacy beliefs among students.

\section{Limitations and Directions for Future Research}

This study provides an example of how psychosocial factors are associated with higher GPAs and greater life satisfaction at a public midwestern university. Due to the sample's demographic homogeneity, the findings may not generalize to other populations. In addition, it is unclear how the findings might relate to different settings, such as community colleges, smaller liberal arts colleges, and specialized institutions such as professional and technical schools. Finally, further research is required to explore the interplay between traditional achievement predictor variables (such as test scores, previous grade attainment), situational variables (such as socioeconomic status, first generation status), and psychosocial variables such as those assessed in this study.

\section{REFERENCES}

American College Health Association. (2009). American College Health Association - National College Health Assessment spring 2008 reference group data report. Journal of American College Health, 57(5), 477-488. doi:10.3200/JACH.57.5.477-488 
Arthur, C., Shepherd, L., \& Sumo, M. (2006). The role of students' diligence in predicting academic performance. Research in the Schools, 13, 72-80.

Arum, R., \& Roksa, J. (2011) Academically adrift: Limited learning on college campuses. Chicago, IL: University of Chicago Press.

Astin, A. W. (1999). Student involvement: A developmental theory for higher education. Journal of College Student Development, 40, 518-529. (Reprinted from the Journal of College Student Personnel, 25, 297-308, 1984)

Bandura, A. (1977). Self-efficacy: Toward a unifying theory of behavioral change. Psychological Review, 84, 191-215. doi:10.1037/0033-295X.84.2.191

Baum, S., \& Ma, J. (2007). Education pays: The benefits of higher education for individuals and society (Trends in Higher Education Series). Mount Vernon, IL: The College Board.

Beltyukova, S. A., Stone, G. E., \& Fox, C. M. (2004). Equating student satisfaction measures. Journal of Applied Measurement, 5, 62-69.

Braxton, J. M., Brier, E. M., \& Steele, S. L. (2007). Shaping retention from research to practice. Journal of College Student Retention, 9, 377-399. doi:10.2190/CS.9.3.g

Chemers, M. M., Hu, L., \& Garcia, B. F. (2001). Academic self-efficacy and first year college student performance and adjustment. Journal of Educational Psychology, 93, 55-64. doi:10.1037/0022-0663.93.1.55

Davidson, W. B., \& Beck, H. P. (2006). Survey of Academic Orientations scores and persistence in college freshmen. Journal of College Student Retention: Research Theory and Practice, 8, 297-305. doi:10.2190/H18T-6850-77LH-0063

DeWitz, S. J., \& Walsh, W. B. (2002). Self-efficacy and college student satisfaction. Journal of Career Assessment, 10, 315-326. doi:10.1177/10672702010003003 
Friedlander, L. J., Reid, G. J., Shupak, N., \& Cribbie, R. (2007). Social support, self-esteem, and stress as predictors of adjustment to university among first-year undergraduates. Journal of College Student Development, 48, 259-274. doi:10.1353/csd.2007.0024

Goodboy, A. K., \& Myers, S. A. (2008). The effect of teacher confirmation on student communication and learning outcomes. Communication Education, 57, 153-179. doi:10.1080/03634520701787777

Gortner Lahmers, A., \& Zulauf, C. R. (2000). Factors associated with academic time use and academic performance of college students: A recursive approach. Journal of College Student Development, 41(5), 544-556.

Handelsman, M. M., Briggs, W. L., Sullivan, N., \& Towler, A. (2005). A measure of college student course engagement. Journal of Educational Research, 98, 184-191.

Kim, E., Newton, F. B., Downey, R., \& Benton, S. (2010). Personal factors impacting college student success: Constructing College Learning Effectiveness Inventory (CLEI). College Student Journal, 44(1), 112-125.

Krumrei, E. J., \& Newton, F. B. (2009). The puzzle of college students success: Fitting the counseling and advising pieces together. National Academic Advising Association Clearinghouse of Academic Advising Resources. Retrieved from http://www.nacada.ksu.edu/Clearinghouse/M02/Counsel.htm

Kuh, G. D., Cruce, T. M., Shoup, R., Kinzie, J., \& Gonyea, R. M. (2008). Unmasking the effects of student engagement on first-year college grades and persistence. Journal of Higher Education, 79(5), 540-563.

Lent, R.W., Brown, S. D., \& Larkin, K. C. (1984). Relation of self-efficacy expectations to academic achievement and persistence. Journal of Counseling Psychology, 31, 352-362. 
doi:10.1037/0022-0167.31.3.356

Lounsbury, J. W., Fisher, L. A., Levy, J. J., \& Welsh, D. P. (2009). An investigation of character strengths in relation to the academic success of college students. Individual Differences Research, 7, 52-69.

Luzzo, D. A., Hasper, P., Albert, K. A., Bibby, M. A., \& Martinelli, E. A. (1999). Effects of selfefficacy-enhancing interventions on the math/science self-efficacy and career interests, goals, and actions of career undecided college students. Journal of Counseling Psychology, 46, 233-243.

Macan, T. H., Shahani, C., Dipboye, R. L., \& Phillips, A. P. (1990). College students' time management: Correlations with academic performance and stress. Journal of Educational Psychology, 82(4), 760-767. doi:10.1037/0022-0663.82.4.760

Mouw, J. T., \& Khanna, R. K. (1993). Prediction of academic success: A review of the literature and some recommendations. College Student Journal, 27, 328-336.

National Center for Education Statistics. (2010). The condition of education 2010 (NCES 2010028). Washington, DC: U.S. Department of Education.

Newton, F. B., Kim, E., Wilcox, D., \& Beemer, N. (2008). College Learning Effectiveness Inventory: Administration and scoring manual for CLEI. Manhattan, KS: K-CAT.

Nonis, S. A., Philhours, M. J., \& Hudson, G. I. (2006). Where does the time go? A diary approach to business and marketing students' time use. Journal of Marketing Education, 28, 121-134. doi:10.1177/0273475306288400

Panori, S. A., Wong, E. H., Kennedy, A. L., \& King, J. R. (1995). A pilot project on college students' satisfaction and self-concept. Psychological Reports, 77, 255-258.

Pascarella, E. T., Pierson, C. T., Wolniak, G. C., \& Terenzini, P. T. (2004). First-generation 
college students: Additional evidence on college experiences and outcomes. Journal of Higher Education, 75(3), 249-284.

Pascarella, E. T., \& Terenzini, P. T. (2005). How college affects students: A third decade of research (Vol. 2). San Francisco, CA: Jossey-Bass.

Pavot, W., \& Diener, E. (1993). Review of the Satisfaction with Life Scale. Psychological Assessment, 5, 164-172.

Peterson, C. H., Casillas, A., \& Robbins, S. B. (2006). The Student Readiness Inventory and the big five: Examining social desirability and college academic performance. Personality and Individual Differences, 41, 663-673. doi:10.1016/j.paid.2006.03.006

Pierson, L. R. (1958). High school teacher prediction of college success. Personnel \& Guidance Journal, 37, 142-145.

Preacher, K. J., \& Hayes, A. F. (2004). SPSS and SAS procedures for estimating indirect effects in simple mediation models. Behavior Research Methods, Instruments, \& Computers, 36, 717-731.

Pritchard, M. E., \& Wilson, G. S. (2003). Using emotional and social factors to predict student success. Journal of College Student Development, 44(1), 18-28. doi:10.1353/csd.2003.0008

Reed, J. G., Lahey, M. A., \& Downey, R. G. (1984). Development of the College Descriptive Index: A measure of student satisfaction. Measurement and Evaluation in Counseling and Development, 17, 67-82.

Richardson, R. C., \& Bender, L. W. (1987). Fostering minority access and achievement in higher education. San Francisco, CA: Jossey-Bass.

Robbins, S. B., Allen, J., Casillas, A., Peterson, H. M., \& Le, H. (2006). Unraveling the 
differential effects of motivational and skills, social, and self-management measures from traditional predictors of college outcomes. Journal of Educational Psychology, 98(3), 598-616. doi:10.1037/0022-0663.98.3.598

Robbins, S. B., Lauver, K., Le, H., Davis, D., Langley, R., \& Carlstrom, A. (2004). Do psychosocial and study factors predict college outcomes? A meta-analysis. Psychological Bulletin, 130, 261-288.

Rocca, K. A. (2010) Student participation in the college classroom: An extended multidisciplinary literature review. Communication Education, 59, 185-213. doi:10.1080/03634520903505936

Russell, R. K., \& Petrie, T. A. (1992). Academic adjustment of college students: Assessment and counseling. In S. D. Brown, R. Lent (Eds.), Handbook of counseling psychology (2nd ed.) (pp. 485-511). Oxford England: John Wiley \& Sons.

Seidman, A. (2005). College student retention. Westport, CT: Praeger.

Sirgy, M. J., Grezeskowiak, S., \& Rahtz, D. (2007). Quality of College Life (QCL) of students: Developing and validating a measure of well being. Social Indicators Research, 80, 343360. doi:10.1007/s11205-005-5921-9.

Smith, D. G. (1977). College classroom interactions and critical thinking. Journal of Educational Psychology, 69, 180-190.

Swail, W. S. (2004, January 23). Legislation to improve graduation rates could have the opposite effect. The Chronicle of Higher Education, 50(20), B16.

Tinto, V. (1987). Leaving college. Chicago, IL: University of Chicago Press.

Tinto, V. (2005). Moving from theory to action. In A. Seidman (Ed.), College student retention (pp. 317-334). Westport, CT: Praeger. 
Weaver, R. R., \& Qi, J. (2005). Classroom organization and participation: College students' perceptions. Journal of Higher Education, 76, 570-601.

Willingham, W. W., Lewis, C., Morgan, R., \& Ramist, L. (1990). Predicting college grades: An analysis of institutional trends over two decades. Princeton, NJ: Educational Testing Service.

Wintre, M. G., \& Yaffe, M. (2000). First-year students' adjustment to university life as a function of relationships with parents. Journal of Adolescent Research, 15, 9-37. doi: $10.1177 / 0743558400151002$

Wright, R. E. (2008). Targeting, segmenting, and positioning the market for college students to increase customer satisfaction and overall performance. College Student Journal, 42, 891-894.

Yeager, M. E. (2009). A cross-validation study of the College Learning Effectiveness Inventory (CLEI) (Unpublished doctoral dissertation). Kansas State University, Manhattan.

Yu, G. B., \& Kim, J. (2008). Testing the mediating effect of the quality of college life in the students satisfaction and student loyalty relationship. Applied Research in Quality of Life, 3, 1-21. doi:10.1007/s11482-008-9044-8

Zhao, C. M., \& Kuh, G. D. (2004). Adding value: Learning communities and student engagement. Research in Higher Education, 45, 115-138. 


\section{Table 1.}

Scales, Descriptions, and Sample Items of the CLEI

\begin{tabular}{|c|c|c|}
\hline Scale & Assesses & Sample items \\
\hline $\begin{array}{l}\text { 1. Academic Self- } \\
\text { Efficacy }\end{array}$ & $\begin{array}{l}\text { Confidence in academic ability, awareness of study } \\
\text { effort, expectation of attaining success in college }\end{array}$ & $\begin{array}{l}\text { I believe it is possible for me to make good grades. } \\
\text { I doubt that I can make the effort to finish college. }\end{array}$ \\
\hline $\begin{array}{l}\text { 2. Organization and } \\
\text { Attention to Study }\end{array}$ & $\begin{array}{l}\text { Organization of tasks, structuring of time, goal setting, } \\
\text { planning, carrying out necessary academic activities }\end{array}$ & $\begin{array}{l}\text { I make study goals and keep up with them. } \\
\text { I wait to study until the night before the exam. }\end{array}$ \\
\hline $\begin{array}{l}\text { 3. Stress and Time } \\
\text { Management }\end{array}$ & $\begin{array}{l}\text { How students respond to time pressure, environmental } \\
\text { concerns, and academic demands }\end{array}$ & $\begin{array}{l}\text { I plan in advance to prevent becoming overwhelmed } \\
\text { with assignments at the last minute. } \\
\text { I feel there are so many things to get done each week } \\
\text { that I am stressed* }\end{array}$ \\
\hline $\begin{array}{l}\text { 4. Involvement with } \\
\text { College Activity }\end{array}$ & Participation in activities, belonging to organizations & $\begin{array}{l}\text { I participate in social activities on campus. } \\
\text { I belong to an organized club on campus. }\end{array}$ \\
\hline $\begin{array}{l}\text { 5. Emotional } \\
\text { Satisfaction with } \\
\text { Academics }\end{array}$ & $\begin{array}{l}\text { Degree of interest in and emotional response to } \\
\text { academic life }\end{array}$ & $\begin{array}{l}\text { I like my courses. } \\
\text { I hate school, but I know I have to do it. }{ }^{\text {a }}\end{array}$ \\
\hline $\begin{array}{l}\text { 6. Class } \\
\text { Communication }\end{array}$ & $\begin{array}{l}\text { Verbal and non-verbal efforts to engage in class } \\
\text { activity }\end{array}$ & $\begin{array}{l}\text { I ask questions in class. } \\
\text { I cannot seem to express my ideas on paper very } \\
\text { well. }\end{array}$ \\
\hline
\end{tabular}

${ }^{\mathrm{a}}$ Reverse scored items. 
Table 2.

Correlations, Means, Standard Deviations, and Internal Consistency for CLEI Scales and College Outcome Variables (N = 579)

\begin{tabular}{|c|c|c|c|c|c|c|c|c|c|}
\hline \multirow[b]{2}{*}{ Variables } & \multicolumn{9}{|c|}{ Correlation coefficient } \\
\hline & 1 & 2 & 3 & 4 & 5 & 6 & 7 & 8 & 9 \\
\hline 1. Academic Self-Efficacy & - & & & & & & & & \\
\hline 2. Organization \& Attention to Study & $.46^{* *}$ & - & & & & & & & \\
\hline 3. Stress \& Time Management & $.35^{* *}$ & $.49 * *$ & - & & & & & & \\
\hline 4. Involvement with College Activity & $.40^{* *}$ & $.37 * *$ & $.16^{* *}$ & - & & & & & \\
\hline 5. Emotional Satisfaction with Academics & $.50^{* *}$ & $.54 * *$ & $.51 * *$ & $.43 * *$ & - & & & & \\
\hline 6. Class Communication & $.39 * *$ & $.44 * *$ & $.40 * *$ & $.36^{* *}$ & $.55^{* *}$ & - & & & \\
\hline 7. $1^{\text {st }}$ Semester GPA & $.36^{* *}$ & $.31 * *$ & $.16^{* *}$ & $.18 * *$ & $.18 * *$ & $.19 * *$ & - & & \\
\hline 8. End-of-year GPA & $.34 * *$ & $.24 * *$ & $.09 *$ & $.12 * *$ & $.09 *$ & $.11 * *$ & $.68 * *$ & - & \\
\hline 9. Life Satisfaction & $.30 * *$ & $.30 * *$ & $.38 * *$ & $.36^{* *}$ & $.37 * *$ & $.27 * *$ & $.09 *$ & $.14^{* *}$ & - \\
\hline$M$ & 4.60 & 3.36 & 3.33 & 3.82 & 3.71 & 3.49 & 3.32 & 3.24 & 3.88 \\
\hline$S D$ & 0.34 & 0.53 & 0.63 & 0.55 & 0.47 & 0.53 & 0.59 & 0.61 & 0.71 \\
\hline Range & $2.8-5.0$ & $1.9-4.9$ & $1.3-5.0$ & $1.6-5.0$ & $2.3-5.0$ & $1.5-4.8$ & $1.2-4.0$ & $0.7-4.0$ & $1.7-5.0$ \\
\hline Cronbach's Alpha & .82 & .80 & .76 & .77 & .67 & .67 & $\mathrm{n} / \mathrm{a}$ & $\mathrm{n} / \mathrm{a}$ & $\mathrm{n} / \mathrm{a}$ \\
\hline
\end{tabular}

Note. $N=557$ for the end-of-year GPA.

$* p<.05 . * * p<.01$. 
Table 3.

Hierarchical Regression Models Predicting GPA ( $\mathrm{N}=579)$

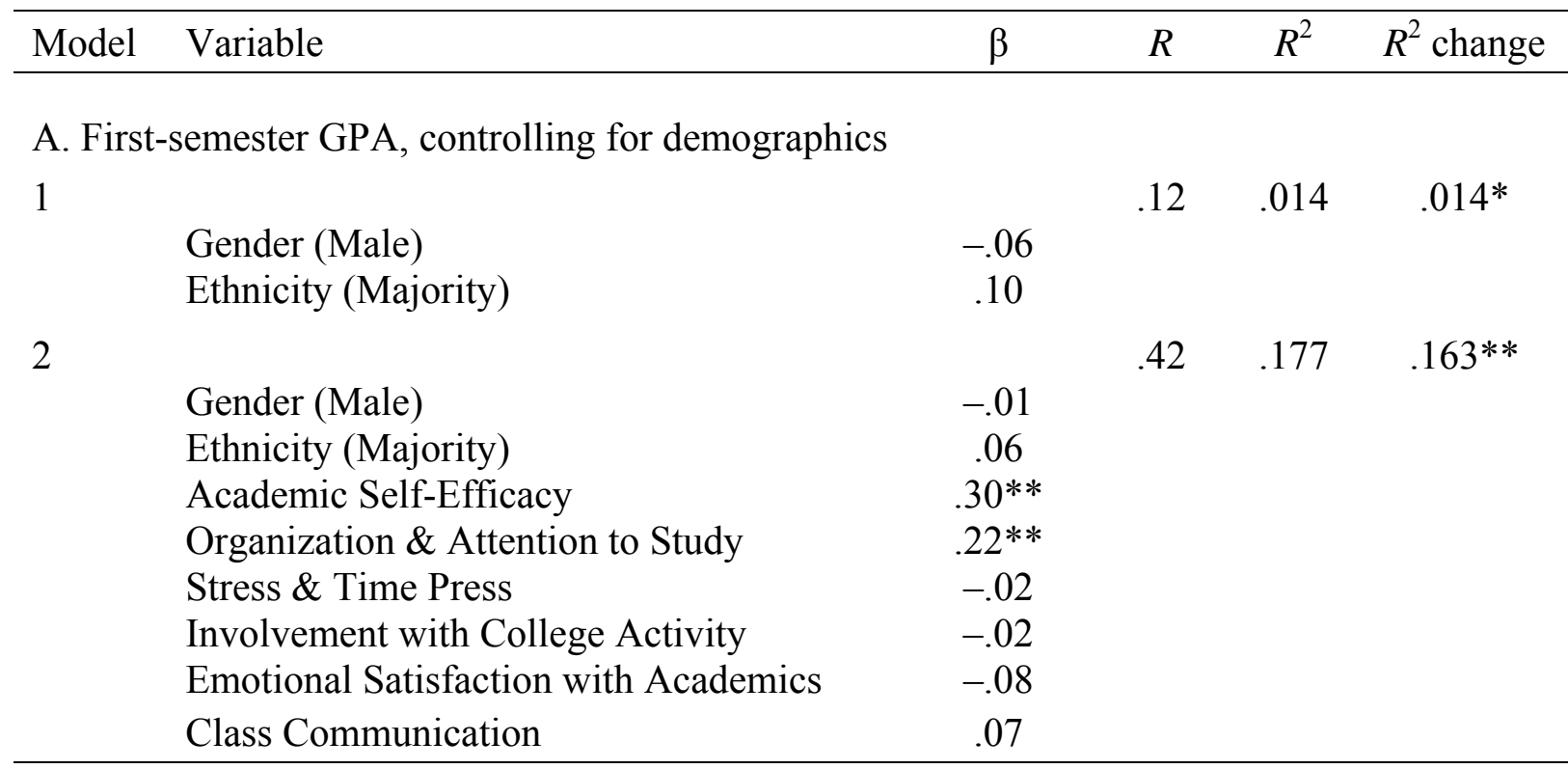

B. End-of-year GPA, controlling for demographics and first-semester GPA

1

Gender (Male)

Ethnicity (Majority)

2

Gender (Male)

Ethnicity (Majority)

First Semester GPA

3

Gender (Male)

Ethnicity (Majority)

First Semester GPA

Academic Self-Efficacy

Organization \& Attention to Study

Stress \& Time Press

Involvement with College Activity

Emotional Satisfaction with Academics

Class Communication
$.15 .023 \quad .023 * *$

$-.09 *$

$.12 *$

.68

$.455 \quad .432 * *$

$.66^{* *}$

$-.01$

.06

$.62 * *$

$.17 * *$

.07

$-.06$

$-.04$

$-.08$

$-.01$

${ }^{*} p<.05 . * * p<.01$. 
Table 4.

First-semester GPA as a Mediator between Psychosocial Factors and End-of-year GPA (N = 557)

A. Indirect effects of Academic Self-Efficacy (ASE) on end-of-year GPA through first-semester GPA, controlling for gender, ethnicity, Organization and Attention to Study, Stress and Time Management, Involvement with College Activity, Emotional Satisfaction with Academics, and Class Communication

Academic Self-Efficacy (ASE)

95\% bias corrected, Proportion of accelerated effect mediated

\begin{tabular}{lccccc} 
Effect & Estimate & $S E$ & $T$ & confidence intervals & $(1-\mathrm{ab} / \mathrm{c})$ \\
\hline $\begin{array}{l}\text { Total effect of ASE on } \\
\text { end-of-year GPA }\end{array}$ & .79 & .11 & $7.17^{* * * *}$ & & \\
$\begin{array}{l}\text { Direct effect of ASE on } \\
\text { end-of-year GPA }\end{array}$ & .40 & .09 & $4.49^{* * *}$ & \\
$\begin{array}{l}\text { Indirect effects of ASE on } \\
\text { end-of-year GPA through } \\
\text { first-semester GPA }\end{array}$ & .40 & .09 & & $(.23, .61)$ \\
\hline
\end{tabular}

B. Indirect effects of Organization \& Attention to Study on end-of-year GPA through first semester GPA, controlling for gender, ethnicity, Academic Self-Efficacy, Stress and Time Management, Involvement with College Activity, Emotional Satisfaction with Academics, and Class Communication

Organization and Attention to Study (OAS) 95\% bias corrected, Proportion of accelerated effect mediated

Effect Estimate $S E \quad T \quad$ confidence intervals $(1-\mathrm{ab} / \mathrm{c})$

Total effect of OAS on end-of-year GPA $.29 \quad .07 \quad 4.00 * * *$

Direct effect of OAS on end-of-year GPA $\begin{array}{lll}.11 & .06 & 1.89\end{array}$

Indirect effects of OAS on end-of-year GPA through first-semester GPA

$\begin{array}{lll}.18 \quad .05 & (.08, .30)\end{array}$


Table 5.

Hierarchical Regression Models Predicting Life Satisfaction, Controlling for Demographics (N = 579)

\begin{tabular}{|c|c|c|c|c|c|}
\hline Model & Variable & $\beta$ & $R$ & $R^{2}$ & $R^{2}$ change \\
\hline \multirow[t]{3}{*}{1} & & & .07 & .005 & .005 \\
\hline & Gender (Male) & .05 & & & \\
\hline & Ethnicity (Majority) & .05 & & & \\
\hline \multirow[t]{9}{*}{2} & & & .50 & .250 & $.245 * *$ \\
\hline & Gender (Male) & .05 & & & \\
\hline & Ethnicity (Majority) & .05 & & & \\
\hline & Academic Self-Efficacy & .05 & & & \\
\hline & Organization \& Attention to Study & -.009 & & & \\
\hline & Stress \& Time Press & $.27 * *$ & & & \\
\hline & Involvement with College Activity & $.26 * *$ & & & \\
\hline & Emotional Satisfaction with Academics & $.10^{*}$ & & & \\
\hline & Class Communication & -.003 & & & \\
\hline
\end{tabular}

$* p<.05 . * * p<.01$ 